\title{
Removals of colour and turbidity from stabilized leachate by using alum and glutinous rice flour dual coagulants
}

\author{
Shaylinda Mohd Zin Nur ${ }^{1, *}$, and Azizan Mohd Omar ${ }^{1}$ \\ ${ }^{1}$ Faculty of Civil and Environmental Engineering, Universiti Tun Hussein Onn \\ Malaysia, 86400 Parit Raja, Batu Pahat, Johor, Malaysia
}

\begin{abstract}
The effects of alum and glutinous rice flour as dual coagulant on the removals of colour and suspended solid from stabilized leachate were investigated. A series of jar test were conducted by optimizing the dose and $\mathrm{pH}$ of single coagulant (alum and glutinous rice flour) and its combination. It was observed that low removals (colour: $46 \%$, suspended solid: $16 \%$ ) were recorded by glutinous rice as single coagulant at $\mathrm{pH} 7$ and dose $1.2 \mathrm{~g} / \mathrm{L}$. However, addition of glutinous rice flour $(0.12 \mathrm{~g} / \mathrm{L})$ as coagulant aid for alum at $\mathrm{pH} 6$ and dose of alum $2.5 \mathrm{~g} / \mathrm{L}$, show better removals of colour $(86 \%)$ and suspended solid $(92 \%)$ from alum. At same $\mathrm{pH}$ and dose of alum as single coagulant, the removals achieved only $79 \%$ and $83 \%$ of colour and suspended solid, respectively. Thus, addition of glutinous rice flour as coagulant aid improved the colour and suspended solid removals from the stabilized leachate
\end{abstract}

\section{Introduction}

Due to increment of population expansion and economic development it will contribute to solid waste generation. According to Diaz and Savage [1], improper solid waste management will poses a hazard to human health and the environment. Uncontrolled dumping area and inconsistent waste handling causes a variety of problems such as contamination of leachate into water bodies. Leachate contain large amount of organic contaminants and hazardous compound such as chemical oxygen demand (COD) and biological oxygen demand (BOD), suspended solids, significant concentration of heavy metals, ammonia, and inorganic salts. If leachate not treat properly and safely disposed it could be a potential source of threat to quality of water. Regarding to Marttinen and Wang [2], usually the treatment of landfill leachate often involves a combination of various method such as aerobic and anaerobic biological process, photo-oxidation and membrane process, chemical oxidation and precipitation, activated carbon and absorption and coagulation-flocculation.

Nowadays, coagulation and flocculation process has been given full priority by many researches in improving the sustainability to the environment [3]. Normally the coagulant

\footnotetext{
* Corresponding author: nursha@uthm.edu.my
} 
use in the treatment of leachate is chemical coagulant such as Alum, Ferric Chloride, Aluminium Sulphate and Polyaluminium chloride (PAC). Even though the uses of chemical coagulant show the good performance and efficiency, some of them causes environmental effect and promote secondary pollution [4]. Therefore, to reduce this problem various study on the efficiency of dual coagulant which consist of chemical coagulant and natural coagulant were carried out. Normally, coagulation just utilized single coagulant, for example, Alum, Ferric Chloride, Aluminium Sulfate and other synthetic coagulant. Hence, the use of dual coagulant consist of chemical and natural coagulant is utilized to enhance the productivity of flocs, and removal colour and turbidity from leachate.

In this research, alum was used as the primary coagulant while glutinous rice flour as the coagulant aids. Alum is one of the conventional chemical coagulant agent used in Malaysia. However, the application of alum produced after used issues such as high volume sludge production and high aluminium content in treated waste water. Application of coagulant aid able to reduced volume of sludge and dose of primary coagulant. However, most of coagulant used is mainly from synthethic polymer material. Which is believed had influence on health issues. Application of natural coagulant is organic and contain no toxic elements. Natural coagulant can be harvest from plant or animal based. Starch is a potential coagulant aid material. The polysaccharides element in starch able to increase the coagulation and flocculation efficiency. Starch is a carbohydrate polymer derived from various sources of food plant structures such as corn, rice, wheat, potato, tapioca, nuts, mung bean, green pea and sago [5]. Unlike most of the existing of natural coagulant, the use of glutinous rice flour as natural coagulant for leachate treatment has not widely been investigate. Hence, this study investigates the effectiveness of dual coagulant consist of alum and glutinous rice flour for the treatment of stabilized leachate by evaluating the colour and turbidity removal.

\section{Methodology}

Samples of stabilized leachate were collected from Simpang Renggam Landfill site (SRL) located in Simpang Renggam, Johor, Malaysia. The sampling procedures for leachate were conducted according to the method of collection and preservation of the samples. All the collected samples were immediately transported to the laboratory and stored in a cold room at $4^{\circ} \mathrm{C}$ to minimize biological and chemical reaction.

Table 1. Optimum coagulation factors determined from preliminary experiment.

\begin{tabular}{|c|c|c|}
\hline $\begin{array}{c}\text { Coagulation } \\
\text { factors }\end{array}$ & Unit & Value \\
\hline $\begin{array}{c}\text { Rapid } \\
\text { mixing } \\
\text { speed }\end{array}$ & RPM & 200 \\
\hline $\begin{array}{c}\text { Rapid } \\
\text { mixing time }\end{array}$ & minutes & 4 \\
\hline $\begin{array}{c}\text { Slow mixing } \\
\text { speed }\end{array}$ & RPM & 30 \\
\hline $\begin{array}{c}\text { Slow mixing } \\
\text { time }\end{array}$ & minutes & 15 \\
\hline Settling time & minutes & 30 \\
\hline
\end{tabular}

Jar test was conducted by using a jar test apparatus. The jar test was performed considering the factors listed in Table $1 . \mathrm{NaOH}(0.1 \mathrm{~mol})$ and HCL $(0.1 \mathrm{~mol})$ were used to 
adjust leachate $(500 \mathrm{~mL}) \mathrm{pH}$. Percentage removals of colour and turbidity were calculated by measuring concentration of aforesaid parameters before and after the jar test.

\section{Results and discussion}

The range of coagulant dose tested was shown in Figure 1. Alum as single coagulant achieved higher removals at dose $5 \mathrm{~g} / \mathrm{L}$ with $99 \%$ and $98 \%$ of SS and colour removals respectively. While application of glutinous rice (GR) coagulant as single coagulant shown higher removals at $1.2 \mathrm{~g} / \mathrm{L}$ with $16 \%$ and $38 \% \mathrm{SS}$ and colour removals. Thus, GR as single coagulant is less effective compare to Alum. Combination of Alum and GR as dual coagulant efficiency are shown in Figure 1 (c). At dose of $3.5 \mathrm{~g} / \mathrm{L}$ alum and $0.12 \mathrm{~g} / \mathrm{L}$ of GR, the best removals were recorded ( $97 \%$ for SS, $89 \%$ for colour). Slightly lower removal of SS (94\%) and colour (88\%) was recorded by single alum at $3 \mathrm{~g} / \mathrm{L}$. At $2.5 \mathrm{~g} / \mathrm{L}$ dose of single alum $83 \%$ and $79 \%$ of SS and colour were removed respectively. At the same dose with addition of $0.12 \mathrm{~g} / \mathrm{L} \mathrm{GR}, 92 \%$ and $86 \% \mathrm{SS}$ and colour removals were recorded. Addition of GR into $<2.5 \mathrm{~g} / \mathrm{L}$ alum able to increase the removal rate of single alum. Thus at lower dosage of alum, GR able to increase the coagulation efficiency. At higher or near optimum value of alum in dual coagulation system, the increment of removal is not that significant. This probably resulted on the dominant removal mechanism during the reaction. At optimum dose of alum in dual coagulation, the action of alum is much more dominant compare to GR. While at point where the alum dose is not optimum, GR reaction able to work together with alum in improving the coagulation efficiency.

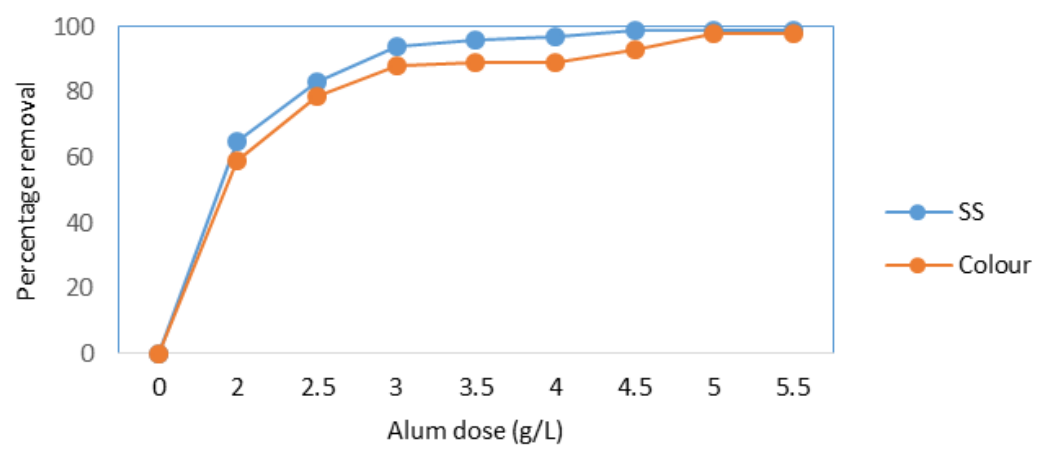

(a)

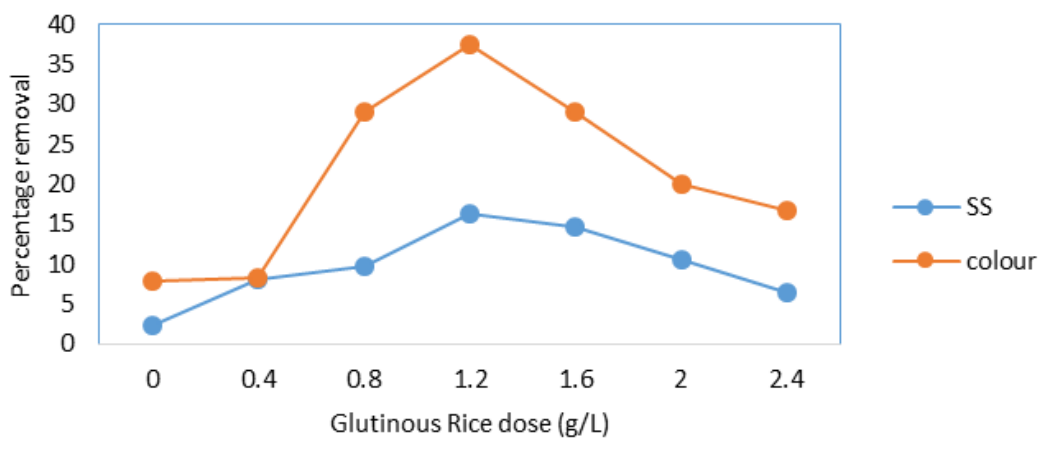

(b) 


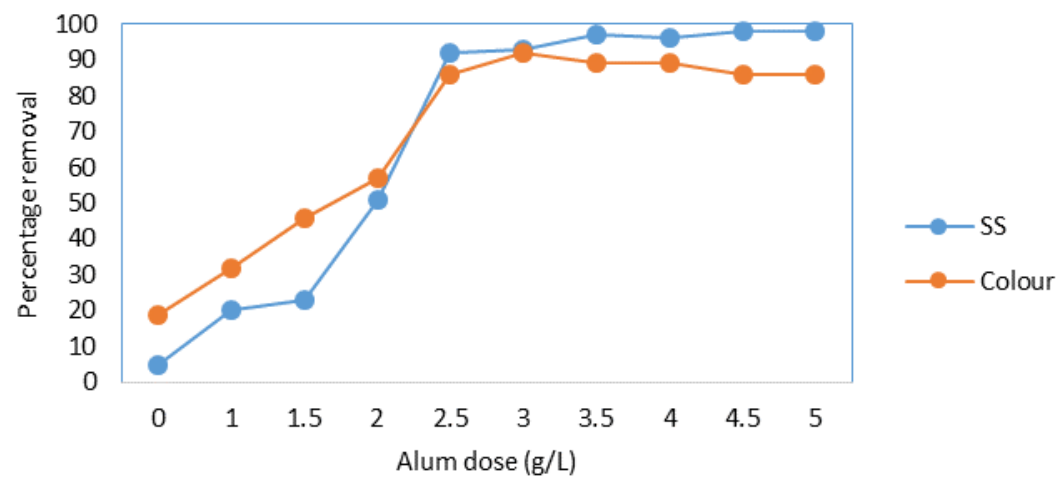

(c)

Fig. 1. Percentage removal of suspended solid and colour under the influence of dose (a) Alum as single coagulant at $\mathrm{pH}$ 6(b) Glutinous rice as single coagulant at $\mathrm{pH} 7$ (c) Dual coagulant ( Alum + $1.2 \mathrm{~g} / \mathrm{L}$ Glutinous rice) at $\mathrm{pH}$.

\section{Conclusion}

The effectiveness of dual coagulant made from alum and GR on stabilized SRL leachates was determined. Dual coagulant optimum removal of SS was recorded at $\mathrm{pH} 6$, alum (4.5 $\mathrm{g} / \mathrm{L})$ and GR $(0.12 \mathrm{~g} / \mathrm{L})$ for $98 \%$ removal. While, for optimum colour removal was at $\mathrm{pH} 6$, alum $(3 \mathrm{~g} / \mathrm{L})$ GR $(0.12 \mathrm{~g} / \mathrm{L})$ with $92 \%$ removal. At lower dose of alum $(2.5 \mathrm{~g} / \mathrm{L})$ with 0.12 $\mathrm{g} / \mathrm{L}$ of $\mathrm{GR}$, the removals of colour and turbidity is better than single alum $(2.5 \mathrm{~g} / \mathrm{L})$ and single GR (1.2 g/L).

\section{Acknowledgement}

This work was supported by Universiti Tun Hussein Onn Malaysia under FRGS grant scheme FRGS Vot 1570. The authors also wish to acknowledge Majlis Perbandaran Kluang for their assistance during the sampling process.

\section{References}

1. $\quad$ L.F. Diaz, G.M. Savage, L.L. Waste Mgmt, 25(6), 626-637 (2005)

2. S.K. Marttinen, R.H. Kettunen, K.M. Sormunen, R.M. Soimasuo, J.A. Rintala, Chem., 46, $851-858$ (2002)

3. K.S. Amit, NR. Mandre, AB. Panda, P. Sagar, Carbo. Pol., 95, 753-759 (2013)

4. Y.B. Song, J. Zhang, WP. Gan, JP. Zhou, LN. Zhang, Ind. Eng. Chem. Res., 49(3), 1242 $1246(2010)$

5. A.J.F. Carvalho, Biopolymers: Biomedical and environmental applications (John Wiley \& Sons, Inc. \& Scrivener Publishing LLC, (2011) 